\title{
Penerapan Metode Analytical Hierarchy Process (AHP) Dalam Sistem Pendukung Keputusan Penilaian Kinerja Guru
}

\author{
M. Andhi Rohmat Basuki ${ }^{1 *}$, Kusrini' ${ }^{2}$ \\ ${ }^{1,2}$ Magister Teknik Informatika Universitas AMIKOM Yogyakarta \\ *andhibasuki@gmail.com
}

\begin{abstract}
The teacher performance appraisal system at SMK Airlangga Balikpapan was carried out as a formality but there was no attempt to improve anything from the school. So we need a performance appraisal system design that can motivate the performance of SMK Airlangga Balikpapan teachers. For this reason, a competency-based teacher performance assessment system was designed, especially the Competence of Academic Qualification Standards and Teacher Competencies combined with Gomes' Competencies. The initial stage is to calculate the weights for each competency using a paired comparison questionnaire, namely the AHP method. Furthermore, an assessment was carried out using a questionnaire using the Rating Scale method. The results of the assessment are processed so that the work performance of each teacher is obtained. As for in this study using 4 criteria and 8 sub criteria. In this research, the application development tool uses the PHP programming language, while the database uses MySQL. The final result of this study found that the decision support system with the AHP method was able to overcome problems in assessing teacher performance at SMK Airlangga Balikpapan.
\end{abstract}

Keywords: Analytical Hierarchy Process (AHP), MyAQL, teacher performance assessment, PHP, rating scale

\begin{abstract}
Abstrak
Sistem penilaian kinerja guru di SMK Airlangga Balikpapan dilakukan sebagai formalitas namun tidak ada suatu usaha perbaikan apapun dari pihak sekolah. Sehingga dibutuhkan suatu rancangan sistem penilaian kinerja yang dapat memotivasi kinerja guru SMK Airlangga Balikpapan. Untuk itu dirancang sistem penilaian kinerja guru berbasis kompetensi, khususnya Kompetensi Standar Kualifikasi Akademik dan Kompetensi Guru yang dipadukan dengan Kompetensi Gomes. Tahap awal dilakukan perhitungan bobot pada tiap kompetensi menggunakan kuesioner pembanding berpasangan yakni dengan metode AHP. Selanjutnya dilakukan penilaian dengan menggunakan kuesioner menggunakan metode penilaian Rating Scale. Hasil dari penilaian tersebut diolah sehingga didapat prestasi kerja dari masing-masing guru. Adapun dalam penelitian ini menggunakan 4 kriteria dan 8 sub kriteria. Dalam penelitian ini alat bantu pembuatan aplikasinya menggunakan bahasa pemrograman PHP, sedangkan basisdata nya menggunakan MySQL. Hasil akhir dari penelitian ini didapatkan bahwa sistem pendukung keputusan dengan metode AHP mampu mengatasi permasalahan dalam melakukan penilaian kinerja guru di SMK Airlangga Balikpapan.
\end{abstract}

Kata kunci: Analytical Hierarchy Process (AHP), MyAQL, penilaian kinerja guru, PHP, rating scale

\section{Pendahuluan}

Guru yang professional diharapkan mampu berpartisipasi dalam pembangunan nasional untuk mewujudkan insan Indonesia yang bertakwa kepada Tuhan Yang Maha Esa, unggul dalam ilmu pengetahuan dan teknologi, memiliki jiwa estetis, etis, berbudi pekerti luhur, dan berkepribadian. Tidaklah berlebihan kalau dikatakan bahwa masa depan masyarakat, bangsa, dan negara, sebagian besar ditentukan oleh guru. Oleh sebab itu, profesi guru perlu ditingkatkan dan dikembangkan secara terus menerus dan proporsional menurut jabatan fungsional guru.

Dalam melakukan penilaian kinerja guru harus mempunyai parameter-parameter yang diantaranya terdapat kriteria dan sub 
kriteria yang telah ditentukan oleh pemerintah atau keputusan dari yayasan untuk sekolah swasta. Proses penilaian saat ini yang dilakukan oleh sekolah SMK Airlangga Balikpapan masih belum memanfaatkan teknologi informasi dan masih bersifat manual, dimana dalam proses itu terdapat pengalihan kriteria dan sub kriteria (Nilai kepentingan) dengan nilai guru.Pengaruh beberapa unsur lainnya seperti hari keagamaan, libur, maupun hari mendekati gajian, dapat mempengaruhi pendapatan pengusaha secara positif ataupun negatif. Pengusaha dapat mengalami kerugian jika mengambil stock barang yang berlebih pada hari-hari dimana minat konsumen sedang berkurang. Sebaliknya, pengusaha dapat meningkatkan penjualannya dengan mengambil stock barang berlebih pada harihari dimana kebutuhan dan minat konsumen sedang bertambah. Hal ini dapat diprediksi dengan mengimplementasikan predictive analytics dalam suatu sistem.

Permasalahan akan timbul pada saat hasil telah keluar dimana dengan masih melakukan perhitungan yang manual akan terdapat output yang tidak rinci, dengan penilaian yang tidak rinci tersebut, dikhawatirkan akan adanya kecemburuan sosial bagi guru yang tidak menerima prestasi. Masalah yang terjadi dalam proses evaluasi (penilaian) kinerja guru diantaranya adalah subjektivitas pengambilan keputusan akan terasa, terutama jika beberapa guru yang ada memiliki kemampuan (dan beberapa pertimbangan lain yang tidak jauh berbeda. Mengacu pada permasalahan dan fokus penelitian di atas, maka peneliti bermaksud untuk menganalisa dan mengembangkan suatu metode perpaduan dengan memanfaatkan informasi berupa prediksi dari metode data mining dan mengkaji serta menyajikan data tersebut dalam bentuk Knowledge Management System sebagai alat pendukung keputusan usaha.

Salah satu metode yang dapat digunakan untuk Sistem pendukung Keputusan adalah dengan menggunakan metode Analytical Hierarchy Process (AHP). Metode ini dipilih karena mampu menyelesaikan menentukan kriteria kinerja guru SMK Airlangga Balikpapan berdasarkan kriteria-kriteria yang sudah ditentukan.

Berdasarkan penjelasan mengenai masalah dan pengajuan solusi diatas, maka temuan dalam penelitian ini adalah keterkaitan dengan penelitian dilakukan penyusun adalah sebagai referensi dan bahan pertimbangan mengenai penentuan penilaian kinerja guru, sehingga cara penghitungan penilaian kinerja guru bisa sesuai dengan keadaan yang terjadi di lapangan dan menghindari kesalahan-kesalahan dalam penilaian kinerja guru yang akan mengakibatkan terjadinya kecemburuan sosial. Dalam menentukan kriteria yang akan digunakan, penyusun melakukan perbandingan dari hasil penelitian sebelumnya lalu digunakan metode AHP untuk memecahkan masalah yang sedang dihadapi yaitu mengenai proses perhitungan dalam penilaian kinerja guru di SMK Airlangga Balikpapan.

Rumusan masalah yang akan diteliti dan dikembangkan adalah sebagai berikut;

1. Penentuan kriteria dan sub kriteria apa saja yang akan digunakan dalam penilaian kinerja guru?

2. Bagaimana membuat rancang bangun aplikasi sistem pendukung keputusan penilaian kinerja guru?

3. Bagaimana menerapkan metode AHP dalam aplikasi sistem pendukung keputusan penilaian kinerja guru?

4. Apakah metode AHP ini dapat menjadi solusi dalam penilai kinerja Guru?

5. Apakah system yang menggunakan metode ini dapat menyajikan informasi yang cepat, tepat, dan akurat sesuai dengan kebutuhan?

Penelitian ini bertujuan untuk melakukan analisis masalah yang berkaitan dengan penilaian kinerja guru (identifikasi kriteria yang akan digunakan dalam model). Menentukan bobot kriteria menggunakan AHP, penentuan peringkat akhir, merancang dan membangun aplikasi sistem pendukung keputusan penilaian kinerja guru yang dapat digunakan oleh Kepala Sekolah untuk memberikan penilaian kinerja gurunya. Sehingga akan membantu Kepala Sekolah dalam menentukan kebijakannya dengan mudah dan tepat untuk merekomendasikan 
kepada guru yang akan mengajukan kenaikan jabatan, pangkat, golongan, dan sertifikasi guru, serta dalam penentuan guru berprestasi berdasarkan peringkat hasil nilai-nya.

Permasalahan yang dibahas dalam penelitian ini terbatas pada topik-topik dibawah ini:

1. Penilaian kinerja guru yang
menggunakan metode AHP dari
beberapa kriteria dan sub kriteria.

2. Mengembangkan system pendukung keputusan yang menggunakan metode AHP yang terintegrasi dengan pemrograman berbasis web.

3. Bagi peneliti lain dapat memotivasi untuk melakukan penelitian berikutnya dan dapat dijadikan bahan pertimbangan untuk lebih mengembangkan aplikasi ini baik untuk permasalahan serupa maupun permasalahan lainnya dengan menggunakan metode yang sama.

Dalam melakukan penulisan ini perlu diberikan beberapa tinjauan pustaka sebagai dasar penelitian, adapun tinjauan pustaka yang berkaitan dengan penelitian adalah sebagai berikut. Artika, 2013, dalam paper berjudul: Penerapan Analytical Hierarchy Process (AHP) Dalam Pendukung Keputusan Penilaian Kinerja Guru Pada SD Negeri 095224. Dalam jurnal ini, peneliti hanya menemukan masalah untuk menentukan kriteria kinerja guru di SD Negeri 095224 masih menggunakan cara yang manual, penilaian kinerja guru sangat penting dalam menentukan guru yang aktif dan berprestasi dalam suatu sekolah salah satu metode yang dapat digunakan untuk Sistem Pendukung Keputusan adalah dengan menggunakan metode Analytical Hierarchy Process (AHP) [1].

Menurut Prasetyowati, dkk, 2013. Dalam paper berjudul: Sistem Pendukung Keputusan Penilaian Kinerja Guru (Pkg) Menggunakan Metode Simple Additive Weighting(SAW) SMA Negeri 9 Semarang. Pada jurnal ini, Kriteria yang dipakai untuk kinerja guru ada 6 yaitu Kesetiaan, Prestasi Kerja, Tanggung Jawab, Ketaatan, Kejujuran dan Kerja sama. Adapun metodenya menggunakan metode SAW [2].
Menurut Dewantoro, Aji, 2013, dalam paper berjudul: Sistem Pendukung Keputusan Menentukan Guru Teladan Di SMPN 24 Semarang Dengan Menggunakan Metode Simple Additive Weighting. Dalam Jurnal ini Metode yang digunakan adalah Metode Simple Additive Weighting. Adapun criteria yang dipakai ada 5 yaitu: Guru menyusun bahan ajar secara runtut, Guru merencanakan kegiatan pembelajaran yang efektif, Guru menerapkan pembelajaran secara efektif, Guru menguasai materi pembelajaran, dan Guru memanfaatkan sumber belajar/media dalam pembelajaran [3].

Menurut Endang Wahyuningsih, 2015, dalam paper berjudul: Sistem Pendukung Keputusan Penilaian Kinerja Guru menggunakan Metode Analytical Hierarchy Process (AHP). Pada jurnal ini menggunakan metode AHP yang dapat membantu seorang pengambil keputusan untuk proses penilaian kinerja guru setiap periode 1 (satu) tahun, sehingga menghasilkan penilaian kinerja guru yang lebih efisien dalam hal waktu, lebih mudah pengadministrasiannya, dan pembuatan laporan lebih cepat [4].

Hsiao, W.-H., T.-S. Chang, M.-S. Huang, and Y.- C. Chen, 2011, dalam paper berjudul: Selection Criteria of Recruitment for Information Systems Employees: Using the Analytic Hierarchy Process (AHP) Method. Pada jurnal menggunakan metode AHP untuk melakukan penelitian mengenai seleksi pegawai Sistem Informasi (SI). Review ahli dan AHP digunakan untuk menganalisis kriteria seleksi yang digunakan dalam perekrutan untuk lima peran SI yang berbeda (proyek manajer, analis sistem, database administrator, programmer dan insinyur sistem). Pegawai SI yang cocok direkrut berdasarkan bobot yang diperoleh [5].

\section{Metoda Penelitian}

Metode yang digunakan dalam penelitian ini adalah metode SDLC (System Development Life Cycle). SDLC merupakan siklus hidup pengembangan sistem. Pengembangan SDLC adalah proses yang digunakan oleh analis sistem untuk mengembangkan sistem informasi, termasuk 


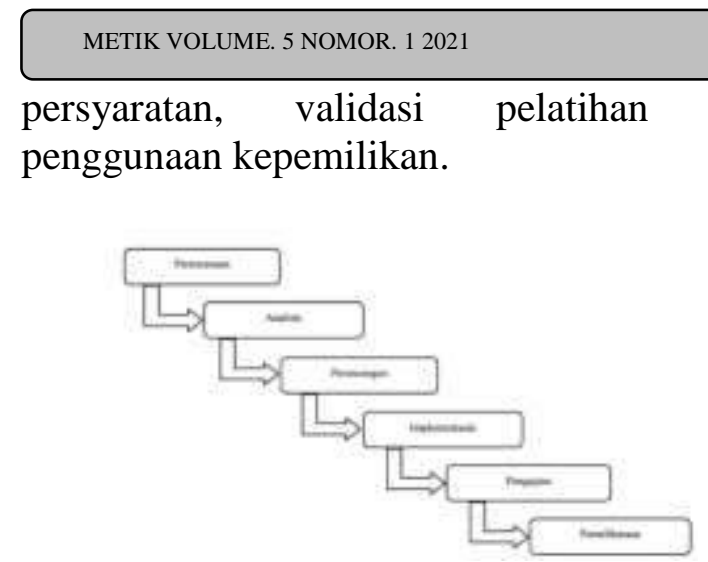

Gambar 1. Kerangka Kerja SDLC

\subsection{Metode Pengumpulan Data}

Metode pengumpulan data pada penelitian ini meliputi beberapa studi yaitu:

a. Studi literature

Mengkaji literature yang ada hubungannya dengan masalah yang dipecahkan agar penulis mendapatkan gambaran yang menyeluruh tentang apa yang telah diteliti orang lain dan bagaimana mengerjakannya, kemudian seberapa berbeda penelitian yang akan penulis lakukan, maka penulis mempelajari dan membaca literaturliteratur yang ada hubungannya dengan permasalahan yang menjadi objek penelitian seperti; buku, jurnal, paper bahkan artikel dari para akademisi.

b. Survei dan pengumpulan data

Survei ke SMK Airlangga Balikpapan, untuk melakukan diskusi langsung dengan Kepala Sekolah sebagai pihak yang berwenang memberikan penilaian kinerja guru, serta melakukan pengumpulan data-data yang diperlukan dalam penelitian ini seperti, data guru, kriteria, sub kriteria penilaian dan sebagainya.

\subsection{Metode Analisis Data}

Ada beberapa tahapan yang dilakukan setelah data terkumpul untuk dianalisis:

a. Mendefinisikan kriteria keputusan

Kriteria penilaian kinerja guru dengan mengacu pada Kemendikbud 2013 factor kinerja menurut Standar Utama Kompetensi Guru yaitu; kuantitas dan kualitas kerja, pengetahuan, kreativitas, kerja sama, keandalan, inisiatif, kualitas personal, kompetensi sosial dan kepribadian,

profesional.

b. Menentukan hierarki structural

Membuat hierarki structural dimana pada bagian atas merupakan tujuan utama permasalahan, lalu terpecah menjadi level tengah (intermediate) berupa kriteria dan sub kriteria, hingga level terbawah yang berupa alternatifalternatif.

c. Melakukan perbandingan berpasangan

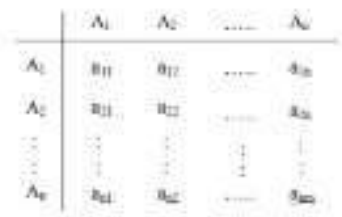

d. Penentuan eigen vektor dan nilai eigen maksimum

Setelah melakukan perbandingan berpasangan, matriks di normalisasi dengan cara masing-masing elemen kolom dibagi dengan jumlah matriks kolom.

Penelitian ini diawali dengan tinjauan pustaka serta pengumpulan data sekunder yang tersedia yang terdiri dari Peta Geologi, Peta Topografi, Peta penggunaan lahan dan juga data geoteknik yang telah tersedia dibeberapa lokasi penelitian [2].

\section{Hasil Penelitian}

Penilaian kinerja guru di SMK Airlangga Balikpapan selama ini sudah melakukan penilaian terhadap prestasi kinerja guru yang dilakukan setiap satu tahun dua kali atau setiap semester. Penilaian kinerja dilakukan oleh supervisi sekolah dalam hal ini kepala program studi atau wakil kepala sekolah bidang kurikulum yang sistemnya mendatangi setiap kelas sesuai dengan jadwal super visi yang sudah dibuat. Dilakukan penilaian terhadap kinerja staff pengajar mereka secara langsung dalam KBM, selain itu juga digunakan beberapa data report pendukung mengenai kinerja masing-masing guru seperti absensi kehadiran, absensi jam mengajar, kesediaan guru dalam mengikuti even sekolah yang diadakan, dll.

Namun penulis melihat sistem yang sudah berjalan ini memiliki kelemahan yaitu sistem penilaian kinerja yang selama ini dilakukan hanya sebatas untuk mengetahui 
hasil kinerja dari seorang guru pada saat KBM dan ketika ikut berpartisipasi dalam kegiatan sekolah tanpa melakukan suatu usaha perbaikan ataupun peningkatan kualitas kinerja guru seperti pemberian reward atau punishment. Hal ini dapat menyebabkan guru di lingkungan SMK Airlangga Balikpapan merasa kurang termotivasi untuk meningkatkan kualitas kinerja mereka.

Dalam penyusunan suatu hierarki untuk menentukan tingkatan tiap level nya maka dibutuhkan informasi yang akurat, dalam hal ini adalah hasil super visi kelas, antar guru dalam satu kantor, tenaga kependidikan maupun warga sekolah di lingkungan SMK Airlangga. Acuan dalam penyusunan hierarki yaitu dengan pengisian kuesioner oleh para responden yang sesuai serta studi literatur pada penelitian sebelumnya mengenai kriteria penilaian kinerja. Semua informasi dari berbagai metode ini akhirnya diperoleh kriteria kinerja guru dengan mengacu pada kriteria atau faktor kinerja menurut Standar Utama Kompetensi Guru [6].

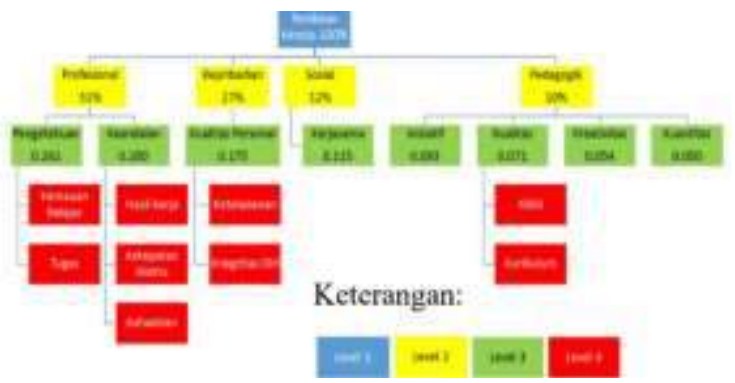

Gambar 2. Hierarki penilaian kinerja guru

Dari Gambar Hierarki penilaian kinerja guru dapat dilihat bahwa struktur hierarki penilaian kinerja guru SMK Airlangga diklasifikasikan sebagai berikut:

1. Level 1 merupakan penilaian kinerja.

2. Level 2 merupakan Standar Kualifikasi Akademik dan Kompetensi Guru.

3. Level 3 merupakan Kompetensi Gomes.

4. Level 4 merupakan breakdown dari sub kriteria dari Kompetensi Gomes.

Tabel 1. Random Index

\begin{tabular}{|l|c|c|c|c|c|}
\hline Ukuran matriks & 1 & 2 & 3 & 4 & 5 \\
\hline RI & 0 & 0 & 0,58 & 0,90 & 1,12 \\
\hline Ukuran matriks & 6 & 7 & 8 & 9 & 10 \\
\hline RI & 1,24 & 1,32 & 1,41 & 1,45 & 1,49 \\
\hline Ukuran matriks & 11 & 12 & 13 & 14 & 15 \\
\hline RI & 1,51 & 1,48 & 1,56 & 1,58 & 1,59 \\
\hline
\end{tabular}

\subsection{Pembobotan Kompetensi}

Pembobotan perlu dilakukan untuk mengetahui tingkat kepentingan dari masingmasing kompetensi dan sub-kompetensi berdasarkan rancangan hierarki pada gambar 2. Dilakukan proses pembobotan kompetensi dengan menggunakan metode Analytical Hierarchy Process yang dibantu dengan software Expert Choice 11. Pada gambar 3 mengenai bobot hasil struktur hierarki penilaian kriteria Kinerja Guru SMK Airlangga Balikpapan, hasil perhitungan untuk menentukan bobot kriteria penilaian yang dibantu dengan menggunakan software expert choice 11 ditunjukkan pada gambar 4 . Perhitungan bobot kriteria pada level 1 berikut ini.

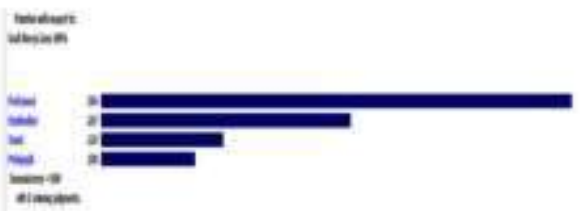

Gambar 3. Perhitungan Bobot Kriteria pada Level 1

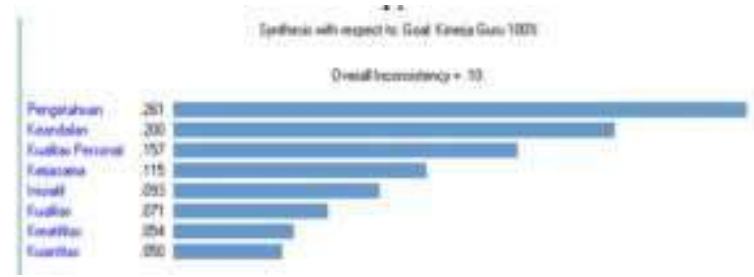

Gambar 4. Perhitungan Bobot Sub Kriteria pada Level 1

Dari gambar bobot hasil struktur hierarki penilaian kriteria kinerja guru SMK Airlangga Balikpapan didapatkan hasil bobot kriteria pada level 2 yang tertinggi adalah kompetensi profesional (51\%), dilanjutkan dengan kompetensi kepribadian (27\%), kompetensi sosial (12\%), dan yang terakhir adalah kompetensi pendagogik (10\%). Untuk penilaian kinerja (level 3) yang memiliki bobot tertinggi adalah pengetahuan (0.261), dilanjutkan dengan keandalan (0.200), kualitas personal (0.175), kerja sama (0.115), inisiatif (0.093), kualitas (0.071), kreativitas (0.054), kuantitas (0.050). Dan pada beberapa kriteria kinerja pada level 3 terlihat masih adanya beberapa breakdown menjadi kriteria kinerja (level 4) yakni pada 
kriteria kompetensi kinerja pada kualitas menjadi KBM (9,62\%) dan Kurikulum $(13,95 \%)$. Kualitas Personal menjadi Keteladanan $(5,85 \%)$ dan Integritas Diri $(5,85$ $\%)$ serta Pengetahuan menjadi Tugas $(5,66 \%)$ dan Kemauan Belajar (1,89\%) sedangkan Keandalan menjadi Hasil Kerja (3,68\%), Ketepatan Waktu $(1,04 \%)$ dan Kehadiran $(2,83 \%)$ yang digambarkan pada kriteria kinerja level 4.

\subsection{Implementasi}

Aplikasi SPK untuk perhitungan nilai kinerja guru menggunakan metode AHP dan menggunakan Bahasa pemrograman, Bahasa yang penulis gunakan adalah Bahasa pemrograman server side (PHP), karena PHP diproses pada komputer server. Hal ini berbeda dibandingkan dengan bahasa pemrograman client-side seperti JavaScript yang diproses pada web browser (client).

Database yang penulis gunakan untuk membuat prototype system ini adalah MySQL, penulis menggunakan database MySQL dikarenakan mempunyai kelebihan diantaranya:

a. Free atau gratis sehingga MySQL dapat dengan mudah untuk mendapatkannya.

b. MySQL stabil dan tangguh dalam pengoperasiannya.

c. My SQL mempunyai sistem keamanan yang cukup baik.

d. Sangat mendukung transaksi dan mempunyai banyak dukungan dari komunitas.

e. Sangat fleksibel dengan berbagai macam program

f. Perkembangan dari MySQL sangat cepat.

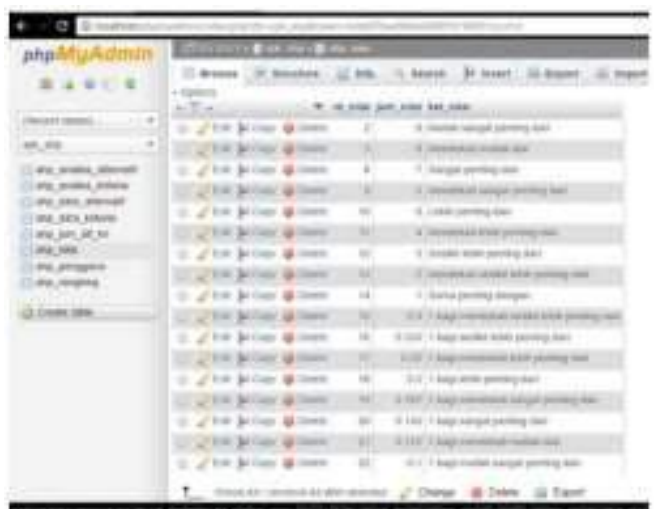

Gambar 5. Database Sistem SPK

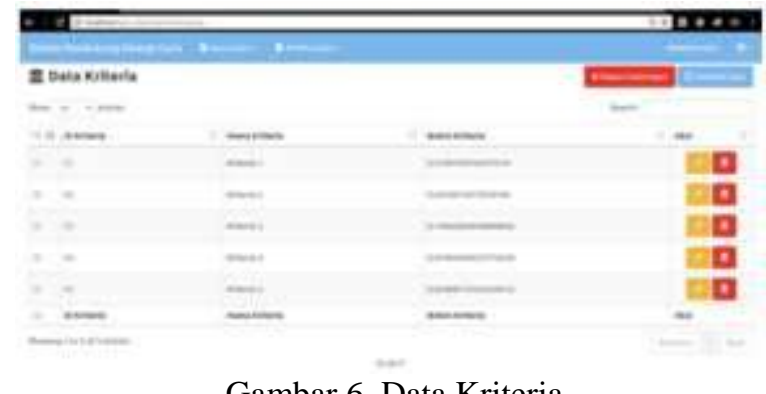

Gambar 6. Data Kriteria

\subsection{Analisis Hasil}

Dari hasil observasi lapangan diketahui morfologi daerah penelitian adalah daerah perbukitan bergelombang dengan lereng \pm $10^{\circ}$, dijumpai bentukan-bentukan erosi gully pada bagian bawah lereng. diketahui bahwa gejala amblesan yang terjadi tidak hanya menunjukan gejala gerakan tanah akibat circular sliding [6].

Tabel 2. Matrik Perbandingan Berpasangan

\begin{tabular}{|l|l|l|l|l|}
\hline Kriteria & $\begin{array}{l}\text { Profesio } \\
\text { nal }\end{array}$ & $\begin{array}{l}\text { Kepri } \\
\text { badia } \\
\mathrm{n}\end{array}$ & Sosial & $\begin{array}{l}\text { Pendago } \\
\text { gik }\end{array}$ \\
\hline Ptofesional & $1 / 1$ & $3 / 1$ & $4 / 1$ & $3 / 1$ \\
\hline Kepribadian & $1 / 5$ & $1 / 1$ & $3 / 1$ & $3 / 1$ \\
\hline Sosial & $1 / 4$ & $1 / 3$ & $1 / 1$ & $2 / 1$ \\
\hline Pendagogik & $1 / 3$ & $1 / 3$ & $1 / 2$ & $1 / 1$ \\
\hline
\end{tabular}

Proses selanjutnya adalah melakukan penjumlahan tiap kolom. Penjumlahan menggunakan 4 (empat) digit dibelakang koma, hal ini berguna untuk pembulatan penghitungan. Adapun hasilnya dapat dilihat pada tabel 3 .

Tabel 3. Hasil bobot Kriteria

\begin{tabular}{|c|c|c|c|c|c|c|}
\hline Kriteria & $\begin{array}{l}\text { Prof } \\
\text { esio } \\
\text { nal }\end{array}$ & $\begin{array}{l}\text { Kepr } \\
\text { ibadi } \\
\text { an }\end{array}$ & $\begin{array}{l}\text { Sosi } \\
\text { al }\end{array}$ & $\begin{array}{l}\text { Penda } \\
\text { gogik }\end{array}$ & $\begin{array}{l}\text { Ju } \\
\text { mla } \\
\text { b }\end{array}$ & $\begin{array}{l}\text { Eige } \\
n\end{array}$ \\
\hline $\begin{array}{l}\text { Profesio } \\
\text { nal }\end{array}$ & $\begin{array}{l}1.00 \\
00\end{array}$ & $\begin{array}{l}3.00 \\
00\end{array}$ & $\begin{array}{l}4.00 \\
00\end{array}$ & $\begin{array}{l}3.000 \\
0\end{array}$ & $\begin{array}{l}11 . \\
000 \\
0\end{array}$ & $\begin{array}{l}0.50 \\
19\end{array}$ \\
\hline $\begin{array}{l}\text { Kepribat } \\
\text { dian }\end{array}$ & $\begin{array}{l}0.20 \\
00\end{array}$ & $\begin{array}{l}1.00 \\
00\end{array}$ & $\begin{array}{l}3.00 \\
00\end{array}$ & $\begin{array}{l}3.000 \\
0\end{array}$ & $\begin{array}{l}7.3 \\
333\end{array}$ & $\begin{array}{l}0.33 \\
46\end{array}$ \\
\hline Sosial & $\begin{array}{l}0.25 \\
00\end{array}$ & $\begin{array}{l}0.33 \\
33\end{array}$ & $\begin{array}{l}1.00 \\
10\end{array}$ & $\begin{array}{l}2.000 \\
0\end{array}$ & $\begin{array}{l}35 \\
833\end{array}$ & $\begin{array}{l}0.16 \\
35\end{array}$ \\
\hline $\begin{array}{l}\text { Pendago } \\
\text { gik }\end{array}$ & $\begin{array}{l}0.33 \\
33\end{array}$ & $\begin{array}{l}0.33 \\
33 \\
\end{array}$ & $\begin{array}{l}0.50 \\
00\end{array}$ & $\begin{array}{l}1.000 \\
0\end{array}$ & $\begin{array}{l}2.1 \\
667\end{array}$ & $\begin{array}{l}0.09 \\
89 \\
\end{array}$ \\
\hline Jumlah & $\begin{array}{l}1.78 \\
33\end{array}$ & $\begin{array}{l}4,66 \\
67\end{array}$ & $\begin{array}{l}8.50 \\
00\end{array}$ & $\begin{array}{l}9.000 \\
0\end{array}$ & $\begin{array}{l}21 . \\
916 \\
7\end{array}$ & $\begin{array}{l}1.00 \\
00\end{array}$ \\
\hline
\end{tabular}

Nilai Consistency Index dengan menggunakan persamaan

$$
\begin{aligned}
& \mathrm{Cl}=\frac{\lambda_{\max }-\mathrm{n}}{n-1} \\
& \mathrm{Cl}=\frac{4.1523-4}{4-1}=\frac{0.21523}{3}=0.0508
\end{aligned}
$$


Untuk $\mathrm{n}=4$, RI (random index) $=0.900$, maka dapat diperoleh nilai consistency ratio $(\mathrm{CR})$ dengan menggunakan persamaan:

$$
C R=\frac{C I}{R I}=\frac{0.0508}{0.900}=0.0627
$$

Oleh karena $C R<0.1$, maka rasio konsistensi dari perhitungan tersebut dapat diterima.

Tabel 4. Perancangan Hasil Penilaian Kinerja Guru

\begin{tabular}{|c|c|c|}
\hline FAKTOR PENILAIAN & $\begin{array}{l}\text { Bobot } x \\
\text { Nilai }\end{array}$ & Skor \\
\hline \multicolumn{3}{|c|}{ KOMPETENSI PEDAGOGIK } \\
\hline Kuantitas & $\begin{array}{l}0,0401 \mathrm{x} \\
5,00\end{array}$ & 0,20 \\
\hline Kreativitas & $\begin{array}{l}0,2070 x \\
2,70\end{array}$ & 0,56 \\
\hline $\begin{array}{l}\text { Kualitas: } \\
\text { 1. Kegiatan Belajar } \\
\text { Mengajar }\end{array}$ & $\begin{array}{l}0,0962 \times \\
3,07\end{array}$ & 0,30 \\
\hline $\begin{array}{l}\text { 2. Kesesuaian Materi dengan } \\
\text { Kurikulum }\end{array}$ & $\begin{array}{l}0,1395 \mathrm{x} \\
3,59\end{array}$ & 0,50 \\
\hline Inisiatif & $\begin{array}{l}0,1442 \times \\
3,43\end{array}$ & 0,49 \\
\hline \multicolumn{3}{|c|}{ KOMPETENSI SOSIAL } \\
\hline Kerja sama & $\begin{array}{l}0,1050 x \\
3,70\end{array}$ & 0,39 \\
\hline
\end{tabular}

\begin{tabular}{|c|c|c|}
\hline $\begin{array}{l}\text { KOMPETENSI } \\
\text { KEPRIBADLAN }\end{array}$ & & \\
\hline Kualitas Personal: & & \\
\hline $\begin{array}{l}\text { 1.Keteladanan } \\
\text { 2. Integritas Diri }\end{array}$ & $\begin{array}{l}0,0585 \mathrm{x} \\
3,48 \\
0,0585 \mathrm{x} \\
3,40\end{array}$ & $\begin{array}{l}0,20 \\
0,20\end{array}$ \\
\hline \multicolumn{3}{|c|}{ KOMPETENSI PROFESIONAL } \\
\hline Pengetahuan: & & \\
\hline $\begin{array}{l}\text { 1.Tugas } \\
\text { 2. Kemauan untuk Belajar }\end{array}$ & $\begin{array}{l}0,0566 \mathrm{x} \\
3,67 \\
0,0189 \mathrm{x} \\
4,00\end{array}$ & $\begin{array}{l}0,21 \\
0,08\end{array}$ \\
\hline $\begin{array}{l}\text { Keandalan } \\
\text { 1. Hasil Kerja } \\
\text { 2. Ketepatan Waktu } \\
\text { 3. Kchadiran }\end{array}$ & $\begin{array}{l}0,0368 \mathrm{x} \\
3,67 \\
0,0104 \mathrm{x} \\
3,33 \\
0,0283 \mathrm{x} \\
5,00\end{array}$ & $\begin{array}{l}0,13 \\
0,03 \\
0,14\end{array}$ \\
\hline Jumlah & & 3,43 \\
\hline
\end{tabular}

\section{Kesimpulan}

System pendukung keputusan dalam menilai kinerja guru dangan menggunakan metode AHP dengan langkah awal yaitu menentukan kriteria dan sub kriteria yang digunakan untuk membuat struktur hierarki. Pada penelitian ini kriteria dan sub kriteria yang telah ditentukan ada 4 kriteria dan $8 \mathrm{sub}$ kriteria yang dalam penghitungan nya dapat menghasilkan ranking yang dapat dijadikan sebagai rekomendasi dalam pengajuan sertifikasi guru, kenaikan pangkat atau golongan. Perancangan system pendukung keputusan dengan memperhatikan kebutuhan dari tempat penelitian dan untuk evaluasi penghitungan kinerja guru yang dilakukan oleh super visi sekolah menggunakan metode AHP sebagai pembobolan kriteria dan menggunakan bantuan software Expert Choice 11 sebagai preferensi ratio kinerja sehingga menghasilkan nilai perbandingan untuk mendapatkan nilai kinerja yang terbaik.

\section{Saran}

Penelitian ini agar dapat menjadi landasan untuk menganalisis kebutuhan dari instansi pendidikan yang berada di daerah yang lain. Berdasarkan analisis dan implementasi yang sederhana, diharapkan hasil penelitian dapat menjadi salah satu bentuk pengabdian kepada masyarakat.

\section{Daftar Pustaka}

[1] Artika, Rini. Penerapan Analytical Hierarchy Process(AHP) Dalam Pendukung Keputusan Penilaian Kinerja Guru Pada SD Negeri 095224. Jurnal: Pelita Informatika Budi Darma. 2013: Volume No.3.

[2] Prasetyowati, Khoirunnisa Rahma, dan Sutojo,. T. Sistem Pendukung Keputusan Penilaian Kinerja Guru (PKG) Menggunakan Metode Simple Additive Weighting (SAW) SMA Negeri 9 Semarang. Skripsi. Semarang: UDINUS. 2013.

[3] Dewantoro, Aji. Sistem Pendukung Keputusan Menentukan Guru Teladan Di SMPN 24 Semarang Dengan Menggunakan Metode Simple Additive Weighting. Tugas Akhir. Semarang: UDINUS.2013

[4] Endang Wahyuningsih, 2015, Sistem Pendukung Keputusan Penilaian Kinerja Karyawan menggunakan Metode Analytical Hierarchy Process (AHP) Studi Kasus diMargaria Group Yogyakarta), penelitian PUSLIT STMIK AKAKOM, Yogyakarta.

[5] Hsiao, W.-H., T.-S. Chang, M.-S. Huang, and Y.-C. Chen. 2011. "Selection Criteria of Recruitment for Information Systems Employees: Using the Analytic Hierarchy Process (AHP) Method." African Journal of Business 
Management 5: 6201-6209.

[6] Kemendikbud. 2013. Pedoman

Pemilihan Guru Berprestasi. 2003.

Jakarta. 